\title{
Smart defence: Joint geospatial support in NATO
}

\author{
Josef Rada ${ }^{1 凶}$ \\ ${ }^{1}$ Department of Military Geography and Meteorology, Faculty of Military Technology, University of Defence in Brno, Brno, Czech \\ Republic \\ јosef.rada@unob.cz
}

\begin{abstract}
Smart defence in NATO may in its very nature represent not only automated remote solutions for battle activities, but harmonized and efficient system of geospatial support of deployed units as well. The objective of this study is to uncover the essence of allied geospatial support mechanism, determine critical spots and propose appropriate system enhancements. Wealth of experience of members of the Armed forces of the Czech Republic was utilized to summarize the state of geospatial support in NATO. It is preferentially experience from foreign operations ISAF and KFOR, cooperation with NATO Headquarters SHAPE and from participation in Multinational Geospatial Support Group. Presented proposals for improvements of geospatial support might have significant impact on intelligence service and military units themselves.
\end{abstract}

Highlights for public administration, management and planning:

- Multinational Geospatial Support Group will become a single complex executive component of NATO geospatial support for foreign operations.

- Financial and capacity means for geospatial support must be centralized directly within NATO structure to reach maximum efficiency.

- Production of standardized-only scale set maps covering territory of NATO and areas of interest is to be obligatorily for all member nations.

- Access to the web service CoreGIS should be granted for all NATO nations at a national level.
Keywords Multinational

Geospatial Support

Group,

Geographic information,

NATO,

Standardization,

CoreGIS

\section{Received:}

04 July 2019

Received in revised form: 03 November 2019

Accepted:

05 November 2019

\section{Introduction}

After almost seventy years of its existence, NATO still stands separated as a military organization in addition to armies of its members. Unifying endeavor is slowly but steadily diffusing among nations. From geo perspective, NATO geospatial cell has a great influence on military and civilian geographic issues of each national member via standardization efforts and joint projects. MN GSG (Multinational Geospatial Support Group) represents significant asset to smart defence projects with overlap to geography in general. Overwhelming majority of people visualizes smart defence as unmanned aerial vehicles used for reconnaissance or conduct of a battle activity. A comprehensive system of geospatial support is certainly a part of smart solutions within the framework of common NATO territory as well. Current trend resides in dealing with web services, remote support, outsourcing and deployment of mobile geo sets (Bortl 2014; Rada 2018). Member states of NATO form a very colorful bloc. Each nation has its own attitude and demands; therefore, a compromise has to be set to reach the smart defence objective, represented by standardization and strategy of unified approach. The aim is to achieve efficient geospatial support in missions abroad or during deployment of NRF (NATO Reaction Forces) in crisis areas. A prospective solution to accomplish this goal is in share of sources and capacities within creation and administration of allied projects, such as MGCP (Multinational Geospatial Co-production Program), and in effort to avoid or reduce duplication of work at the same time. 


\section{Methods of analysis}

The aim of the paper is to provide information upon Smart Defence Initiative of NATO and the GENT Initiative of the EU, specifically the project 2.50 Establishing of a Multinational Geospatial Support Group, analyze initial shortcomings and eventual optimal goals. The analysis of the structure of geospatial support in NATO is rather confidential topic, something that is not usually being publicly presented, especially due to a classification level of respective information or data. Nevertheless, open sources and services are utilized more and more and collaboration between armies, civil sector and European Union expands progressively. The system has become more open, albeit, it might be relatively incomprehensible due to its complexity. The incentive for the analysis of geospatial support in NATO is defining the essence of functioning of this process, determining critical spots and proposing suitable enhancements of the system.

Official documents which define geospatial support in NATO were analyzed for these purposes (NSO 2016, 2017). Directions and regulations concerning NATO expert groups have been studied as well. A key element of the paper is a process Lessons Learned used in the army to summarize experience from posts in missions abroad. The major geo positions incorporated in the study are from the structure of geospatial support in NATO, Chief Geospatial Officer in KFOR (Kosovo Force), liaison officer for web services and geo courses in SHAPE (Supreme Headquarters of Allied Powers in Europe) (Marša 2010), database manager in SHAPE (Supreme Headquarters of Allied Powers in Europe), national representatives in NATO technical groups, e.g. MNGSG (Multinational Geospatial Support Group).

The essential part was also a digest of main findings of official documentation. For instance, the military document Pub-28-68-03 “Geografické zabezpečení operací" (MO ČR 2016) comprises of more detailed information regarding all aspects of geospatial support in the NATO alliance. Sources of Office of Military Geography and Hydrometeorology (VGHMÚř) were used as basic data and additional information. VGHMÚr as a primary production unit of the armed forces of the Czech Republic cooperates also with neighboring and other European countries (Marša 2014) through a system of agreements and contracts. In other words, collaboration with adjacent states enables closer look to approach of other armies to joint geospatial support.

\section{Results}

\subsection{Overview of the topic}

Geospatial support in NATO has its particular place in the chain of command. The essential characteristic of individual NATO headquarters is multinationalism. This feature is equally enriching as limiting. Each national military geospatial service brings its own experience and traditions into what can be called "common approach". The downside is that a full consensus cannot be reached in such a diverse community. From 1949 until 2009, NATO grew from 12 to 28 allies, with 12 entrants after 1998. These newest allies brought a greater heterogeneity to NATO in terms of their defense capabilities, their relative locations to Russia, their defense preferences, and their industrial base (George 2018). Aforementioned diverse attitude of respective NATO members can be further explained through a position of each nation in the matter of financial means, population, area, number of military personnel and overall ranking which was calculated as a combination of all elements. A comparison of diversity of NATO nations is in Table 1. The overall rank represents involvement of each nation in NATO matters, deployment of forces and in general military power. In figurative sense, a way of geospatial support in NATO is directly influenced by the order in Table 1 . The higher position in the overall rank, the stronger voice and influence nation has. First five nations in the list have most control and presence in geo-related projects and groups. The only exception is Turkey, which is undergoing an international crisis. Its recent political and military actions caused mistrust among allies leading into lesser participation of Turkey in various NATO issues.

As for the military geospatial specialists, their involvement and ratio are directly connected to resultant rank in Table 1. Neither numbers of geospatial personnel, nor extent of production can be directly published; nevertheless, it is obvious that substantial discrepancies can be observed. For instance, the Czech Republic has almost three times more of geo personnel than Slovak Republic; however, the Czech army is only 50\% larger than Slovak army. The military geographical service of the Army of the Czech Republic (GeoSl AČR) may ensure complete coverage of map production of own territory and simultaneously significantly cooperate on international projects of NATO.

The attached diagram in figure 1 shows national ratio in NATO of personnel involved in geospatial 
Table 1 General comparison of NATO countries

\begin{tabular}{|c|c|c|c|c|c|c|}
\hline $\begin{array}{l}\text { NATO } \\
\text { countries }\end{array}$ & $\begin{array}{l}\text { GDP } \\
\text { (\$ in billion) }\end{array}$ & $\begin{array}{l}\text { population } \\
\text { (in million) }\end{array}$ & $\begin{array}{l}\text { area } \\
\text { (in sq km) }\end{array}$ & $\begin{array}{l}\text { military pers } \\
\text { (in thousand) }\end{array}$ & $\begin{array}{l}\text { army budget } \\
\text { (\% of GDP) }\end{array}$ & $\begin{array}{l}\text { overall } \\
\text { rank }\end{array}$ \\
\hline Albania & 13.12 & 3.01 & 27400 & 6.80 & 1.10 & 25 \\
\hline Belgium & 483.71 & 10.44 & 30280 & 27.00 & 0.90 & 19 \\
\hline Bulgaria & 51.03 & 6.98 & 108610 & 25.00 & 1.53 & 15 \\
\hline Canada & 1820.00 & 34.57 & 9090000 & 71.00 & 1.29 & 7 \\
\hline Croatia & 56.44 & 4.48 & 53910 & 15.00 & 1.26 & 21 \\
\hline Czech Republic & 195.66 & 10.16 & 77250 & 25.00 & 1.05 & 16 \\
\hline Denmark & 314.24 & 5.56 & 42430 & 17.00 & 1.17 & 17 \\
\hline Estonia & 21.85 & 1.27 & 42390 & 6.10 & 2.08 & 24 \\
\hline France & 2610.00 & 65.95 & 547660 & 208.00 & 1.79 & 2 \\
\hline Germany & 3400.00 & 81.15 & 348770 & 183.00 & 1.24 & 5 \\
\hline Greece & 249.10 & 10.77 & 128900 & 105.00 & 2.36 & 9 \\
\hline Hungary & 125.51 & 9.94 & 89610 & 19.00 & 1.06 & 18 \\
\hline Iceland & 13.66 & 0.32 & 100250 & $\mathrm{x}$ & $\mathrm{x}$ & 28 \\
\hline Italy & 2010.00 & 61.48 & 294140 & 180.00 & 1.12 & 8 \\
\hline Latvia & 28.32 & 2.18 & 62250 & 6.30 & 1.75 & 23 \\
\hline Lithuania & 42.09 & 3.52 & 62680 & 15.00 & 1.73 & 20 \\
\hline Luxembourg & 57.12 & 0.51 & 2590 & 0.80 & 0.46 & 29 \\
\hline Montenegro & 4.23 & 0.65 & 13812 & 1.70 & 1.58 & 26 \\
\hline Netherlands & 772.23 & 16.81 & 33760 & 41.00 & 1.15 & 14 \\
\hline Norway & 499.67 & 4.72 & 304280 & 20.00 & 1.62 & 12 \\
\hline Poland & 489.80 & 38.38 & 304250 & 118.00 & 1.99 & 6 \\
\hline Portugal & 212.45 & 10.80 & 91500 & 30.00 & 1.31 & 13 \\
\hline Romania & 169.40 & 21.79 & 229890 & 59.00 & 1.80 & 11 \\
\hline Slovak Republic & 91.60 & 5.49 & 48100 & 13.00 & 1.19 & 22 \\
\hline Slovenia & 45.28 & 1.99 & 20140 & 6.80 & 0.98 & 27 \\
\hline Spain & 1350.00 & 47.37 & 498980 & 121.00 & 0.92 & 10 \\
\hline Turkey & 789.26 & 80.69 & 769630 & 386.00 & 1.48 & 4 \\
\hline United Kingdom & 2440.00 & 63.18 & 241930 & 145.00 & 2.12 & 3 \\
\hline United States & 15680.00 & 316.67 & 9160000 & 1314.00 & 3.57 & 1 \\
\hline total & 34035.77 & 920.83 & 22825392 & 3165.50 & & \\
\hline
\end{tabular}

source data Statista 2018; Nation Master 2018. Overall rank is based on a sum total of ranks in individual characteristics ordered from minimum to maximum.

support. The diagram uncovers the most important facts in the alliance. The USA represents independent force and is capable of developing its own global projects and services. The second group, United Kingdom, France and Germany, bears most of the financial and personnel capacities of joint NATO groups. The third group, of which the Czech Republic is the ideal candidate, provides only specific capabilities and shares limited capacities. Nations as Turkey and Greece do not possess complete variety of geo-related capabilities. Their main concern is to build up a large army consisting of higher proportion of ground battalions. Total number of geo personnel is though dispersed among many ground units. These assigned officers focus on common geospatial support and do not develop any deeper specialization.

The picture on the right side Fig. 1 shows percentage of geo personnel to individual member nations of NATO, the order is the same as at the left picture. Smaller nations with higher ratio of geo personnel to military are on the left side of the graph. A smaller peak in the middle symbolizes medium sized nations (the Czech Republic, Netherlands) and on the right at the end are the USA.

\subsection{The structure}

Although the system of geospatial support in NATO leans on capacities and means of member states, it is hard to distinguish a common element of national systems in NATO hierarchy. The highest geo-related technical institute of NATO is a geocell at the headquarters SHAPE. It leads the whole system of NATO geospatial support conceptually. SHAPE geocell also plans a production, gathers data, manages designation and standardization of map products and supports directly SHAPE com- 


\section{Sciendo}

mand itself. A major function of subordinated headquarters JFC (Joint Force Command) is leadership and remote support of missions abroad. Commands of individual sorts of military (army, air, navy) focus on their specific activity and so are rather considered as end users.

The alliance does not have its own production sector. This is secured by sources and capacities of member states, yet lesser capacities and financial means are directly at disposal of SHAPE. These funds cannot be applied globally on every issue, thence they are utilized primarily to cover crisis areas mostly by acquisitions of data or assigning a task to a civilian agency NCIA (NATO Communication and Information Agency) which has broader capabilities. Creation of own datasets is considered as a last resort due to limited capacities.

Missions abroad and crisis areas, such as Baltic or Mediterranean region, need additional support due to a large number of tasks and products required to cover individual needs of these missions. The idea is to assign these tasks to one nation, called TISN (Topographic Information Supporting Nation). Members of NATO take turns as a leader of geospatial support. With this system, the TISN is able to cover one major mission, significantly improving the service provided by remote support. Alliance forces deployments has grown in numbers in recent years; thus, the current system cannot reflect all the needs, mainly of secondary missions.

TISN bears all costs of geospatial support during its responsibility period which is exactly one year. Ability to cover whole range of geo tasks, capabilities and technical solutions could be a limitation. The other problem resides in provision of EU missions because EU military headquarters does not have more developed geo hierarchy to cope with all requirements. A new multinational geospatial support group was established to share capabilities and capacities of those nations willing to join this project. MN GSG is not directly subordinated to SHAPE. The reason for its independce on the NATO hierarchy is its support of both NATO and EU missions. Not all nations participating in MN GSG are members of NATO.

\subsection{Standardization}

Unitary rules covering whole range of map products and services are generally called standardization procedures. Enforcement of standardization to all NATO members is exceedingly difficult matter. First of all, there is designation of data, an important procedure of data standardization from various sources with different history (Kovař́k 2016). After decades of collaboration with aim to unify geospatial support throughout the alliance, a large num-
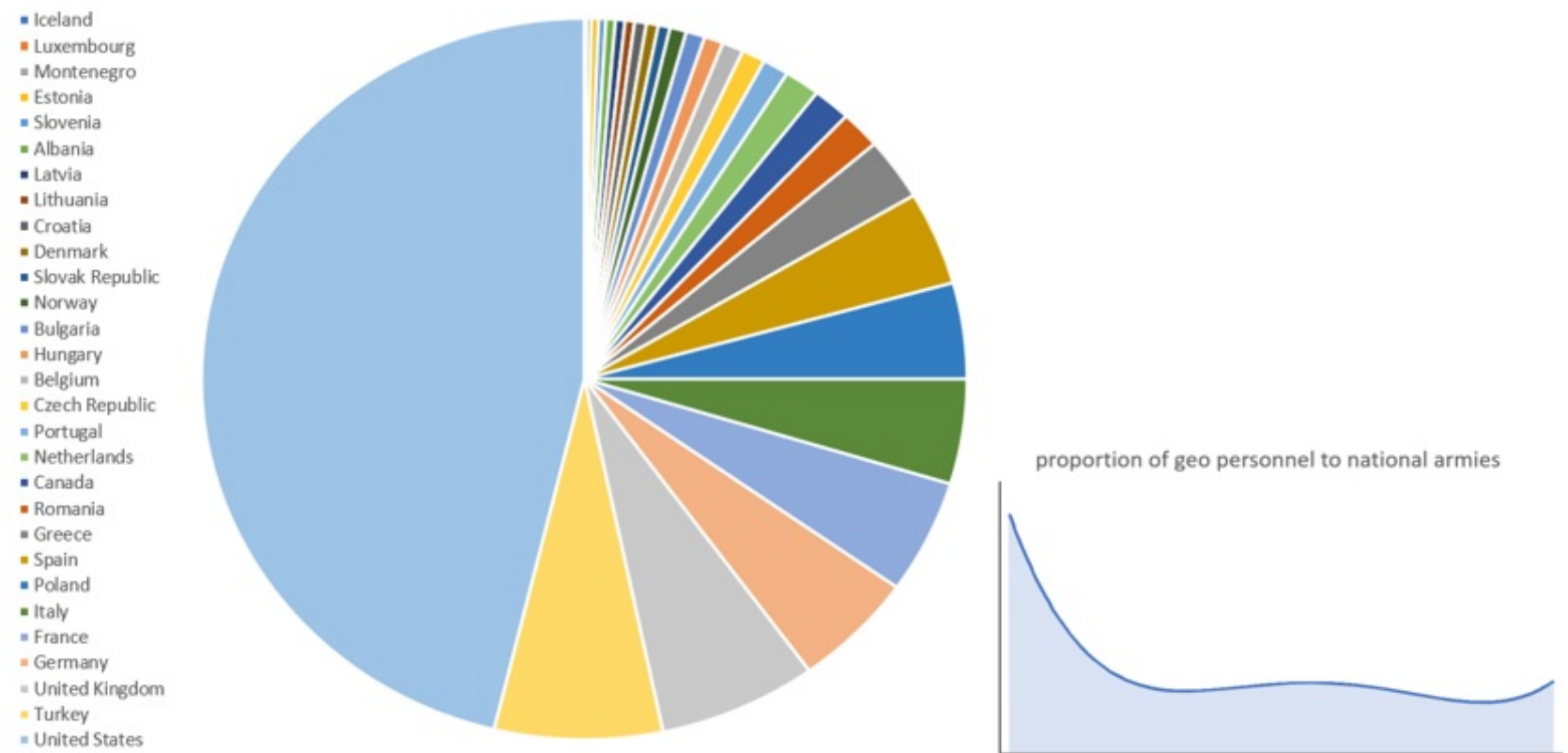

Fig. 1 Proportion of personnel in geospatial branch in NATO. The ratio is gathered from Table 1 and known numbers of geo personnel in NATO. On the right: Proportion of geo personnel to individual national armies (values are hidden due to security reasons). 
Table 2 Extent of map products in NATO

\begin{tabular}{|c|c|c|c|}
\hline types of maps & lower scale limit & upper scale limit & notes \\
\hline maps of smaller scales & 1: 250000 & 1: $1 \mathrm{mil}$ & other smaller scales are not being updated \\
\hline maps of medium scales & 1: 25000 & 1: 100000 & $\begin{array}{l}\text { basic map in original NATO countries } \\
\text { is topographic map 1: } 50000 \\
\text { basic map in post-communist countries } \\
\text { is topographic map 1: } 25000\end{array}$ \\
\hline maps of larger scales & $\mathrm{x}$ & 1: 10000 & $\begin{array}{l}\text { are being produced only in crisis areas } \\
\text { and only by bigger NATO nations }\end{array}$ \\
\hline
\end{tabular}

ber of groundbreaking changes at a national level have been achieved. Even though, many sensitive gaps difficult to overcome still remain. Contemporary issue of such kind is unification of topographic maps 1:50 000. Preparations to implement the standard are already under way in the Czech Republic, yet, many nations are still against this idea. For example, there is a long-time tradition of creation of topographic maps in the Czech army. Their quality is at a high level after 70 years of continuous update and production. From this point of view, implementation of the standard would be a step back. On the other hand, unification of NATO maps is the advantage that might prevent doing errors and mistakes when reading various national versions of topographic maps. Maps of smaller scales, e.g. JOG 250 (joint operation graphic 1: 250.000), are already standardized (NATO 1979), so expanding of the system to maps of medium scales seems to be a logical step. A basic scheme of classifying NATO maps is in Table 2.

\subsection{Common geo products of NATO}

Recently, NATO policy emphasizes that its nations should decide to shift a far greater proportion of NATO forces and capabilities to its eastern allies, including the permanent stationing of land, air, and sea forces in the Baltic States, Poland, Romania, Bulgaria, and in the Arctic (Burns 2016). Unified geospatial policy is also based on a principle of sharing of national capacities for creation of common standardized geospatial products. Every nation secures its own territory with the exception of mentioned countries, where joint effort as well as external help should be directed. As far as a global scale and crisis areas out of NATO territory is concerned, it is necessary to incorporate sources of all members to produce high quality and detailed geospatial data from distant territories mostly without any available additional data and information. Contemporary, two joint projects have the biggest attention of NATO MGCP and T-Rex.
Multinational Geospatial Co-production Program (MGCP), commenced in 2005, is a project of which outcome is a vector database as an equivalent of topographic maps scale 1: 50000 (Wildmann 2009). Cells for processing (basic area of responsibility) have been assigned to respective participants of the project. A system of credits serves as a motivation for participating states. The more cells are processed by one nation, the more additional cells the nation can download. The Czech Republic has produced over 50 cells so far, and so is allowed to download five times more cells than it has provided.

TanDEM-X High Resolution Elevation Data Exchange Program (TREx) is based on a satellite radar system TanDEM-X capturing data in a 12-meter resolution. The principles of international cooperation are in essence adopted from already existing active project MGCP. A basic element for processing radar data is area of $1^{\circ} \times 1^{\circ}$ (cell). Participating nations can get back proportional part of own cumulated credit gained by processing assigned data. The GeoSl ACR has signed up to process 40 cells and by finishing it, get four times more cells in return. The total number of 120 cells responds to coverage of all areas where Czech military units are deployed (Bělka 2015).

\subsection{CoreGIS}

Provision of military units with paper maps is gradually superseded by a direct support in a form of web services. This tendency follows a principle "work on the same map". A web service CoreGIS is distributed via internal NATO network (NATO secret). It is a standardized type of geospatial web service where all the designated data is published, which means unified data fulfilling NATO standards (NSO 2013, 2016). It comprises these sorts of data:

- Base data

- Raster maps

- Aerial and satellite imagery

- Vector databases 


\section{Sciendo}

- Special data

- Miscellaneous maps - a system of preproduced maps tailored to a respective mission abroad

- Mission Specific Product - maps created for a single task

Datasets are organized in three main folders according to a height of echelon they represent. Strategic databases (SDB) cover whole territory of NATO. Operational databases (ODB) encompass only one mission abroad or command. Tactical databases (TDB) are produced and administered only by one workplace at a lower echelon. Tools for work with a map composition are integral part of CoreGIS. This allows local GIS managers on each command to effortlessly create own map or dataset. NATO HQ geocell does not have its own development branch. CoreGIS web service and other pre-planned research projects are usually assigned to the civilian agency NCIA.

\subsection{MN GSG}

This international group operating under auspice of NATO was established in 2016 primarily with intention to enhance remote support of NATO and EU missions. MN GSG is situated in Euskirchen, Germany, at the compound of Geocenter of Bundeswehr. The key concept resides in collective sharing of personnel, production and material capacities of NATO and EU nations (MN GSG 2017).

Individual nations that have acceded to this group can offer following capabilities:

- Personnel

- Data

- Printing

- Survey groups

The objective is to fill the gaps in geospatial support of foreign missions. MN GSG undertakes such kind of tasks which are unfeasible or overly capacitively demanding at a place of deployment of troops. It includes in particular large scale printing (e.g. various atlases), special map products or analyses and development of map services. Furthermore, MN GSG declares available survey groups for various survey tasks, e.g. measurement of high-rise objects or airfields (MN GSG 2018). A joint exercise is organized annually to ensure high level of survey skill. The exercise will be held in the Czech Republic at the former military airfield Bechyně in 2020.

\section{Discussion}

The obvious fact arises from the analysis of the structure of geospatial service in NATO. Even though, there is ongoing streamlining of services and projects, duplication of work still exists. The goal of below presented proposals is to highlight the most problematic parts and briefly indicate a way how to sort them out.

\subsection{Reduction of outsourcing}

Outsourcing, or else, procurement for development of services and products has both pros and cons. This form of handling of projects is more financially demanding than maintaining own smaller group of specialists. Outsourcing is also overly binding. A national geographic service which lacks ability of processing some sort of tasks will eventually end up reliant solely on an external agency and is obliged to a paid maintenance of products in the long term. The asset, on the contrary, is that tasks are built up as "turnkey" solutions and a customer takes care only of defining a product and in the fullness of time taking over a result. GeoSl AČR keeps its own specialists in the branch of development, web solutions and programmers. It can maintain and provide military with the web geographical service mapy.acr at acceptable costs. It contains all essential military geographical data and information and other analytical modules (Kopecký 2013). Nonetheless, the Army is also provided with Operational Tactical Systems web service, which operates on the same principle. After many years in operation it covers large part of military units in the Czech Republic, comprises own particular data and modules and most importantly, it is restricted. Development, data gathering and overall maintenance is outsourced, thus, processed by a civilian company. Costs of such a solution are substantially higher than maintaining of a system using own sources and capacities, however, some capabilities and specialists are hard to keep, mainly in the field $\mathrm{wms} / \mathrm{wfs}$ restricted solutions.

It would be appropriate to apply the same approach used in the Czech Republic to NATO. By all means, more complex projects would continue on being outsourced, as it is impossible to have experts in all fields. Nevertheless, the way of simple tasks of development processed within capacities of NATO is definitely cheaper and faster option. Complexity of tasks is becoming too challenging even for GeoSl AČR, thus civilian companies will be tasked more 
frequently to support the Czech army with certain geospatial services in the foreseeable future.

\subsection{Strengthening of MN GSG position}

Slightly adjusted form of current system of geospatial support seems to be the ideal option. SHAPE works already as a leading center, although, with shortage of personnel. Specialists in research and development should be incorporated in the system of geo posts. NCIA would continue as a developing center, nonetheless, with limited scope of work. A role of TISN should be diminished as well, as it ought to be formed just formally to augment number of personnel of MN GSG. In case of crisis, personnel would be added from capacities of respective TISN, similar to combat readiness represented by current status of NATO Reaction Forces (NRF).

This implies that MN GSG would take over a significant portion of scope of TISN enabling it to cover most of the reach-back support. Current numbers would then be doubled even during a non-crisis period. This way, new specialists in development and database operators would be a part of MN GSG, thus enabling to secure a production of maps or databases. With the extended responsibility, MN GSG would become a complex executive component of NATO and EU. The budget is more transparent and diversity is superseded by standardization and more consistent unified attitude.

The following time line Fig. 2) shows formation of the group, its expansion and growth on numbers and intended direction of development contained in the official documentation.

\subsection{Deepening of a concept of unitary prod- ucts}

NATO should enhance its civilian and military intelligence sharing and coordination, among allies and with key partners in the Middle East and North Africa (Burns 2016). Geospatial support as a part of military intelligence can contribute with standardization and common map and data production (MGCP, TREx). Ideal state can be summarized into these points:

- NATO nations are responsible for its own territories;

- Data is exchanged at maximum extent among NATO members;

- Each member is active contributor to shared data storage;

- Processing of standardized scale set covering territory of NATO and areas of interest;

- Production and regular update of topographic maps scale 1: 50 000, 1: 100000 and 1: 250 000 .

\subsection{Development of web solutions}

CoreGIS is being used in all NATO commands without any problems. Availability and speed of network connection vastly limit usage of this service in missions abroad. Furthermore, there is a problem with two networks, a NATO secret and a MISSION secret. Although NATO secret, which runs

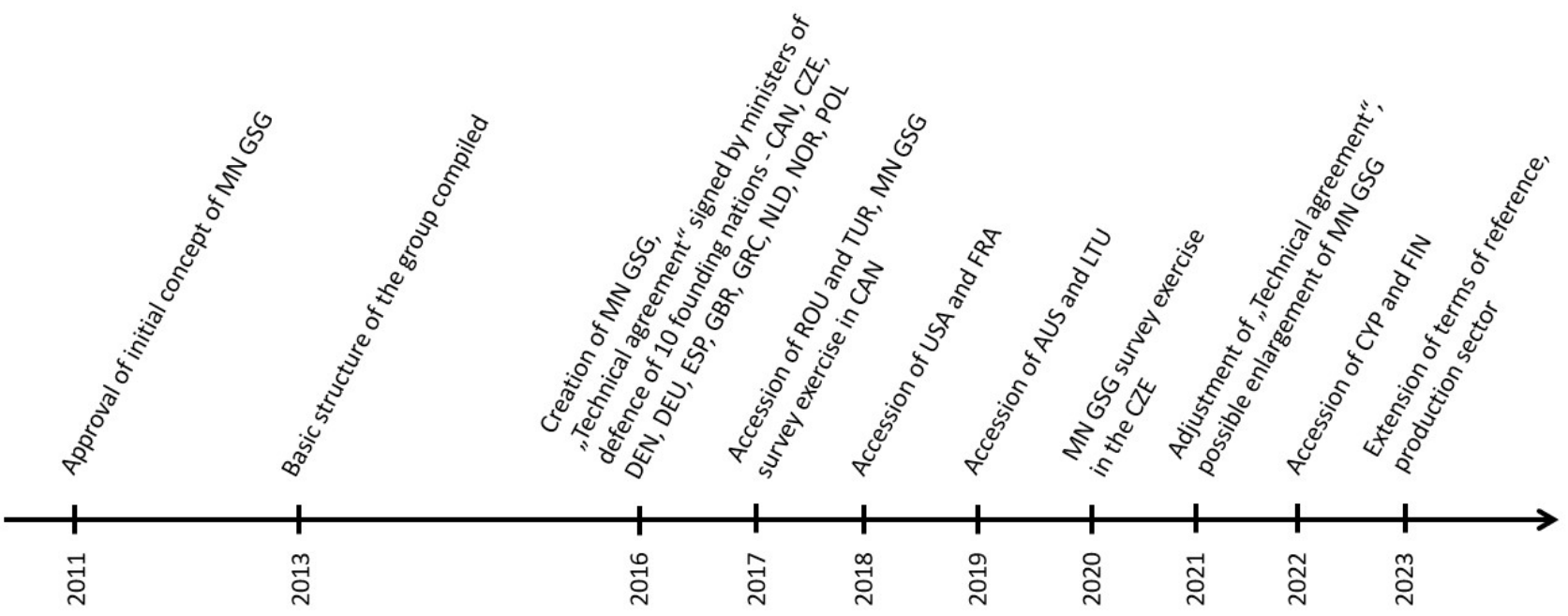

Fig. 2 Timeline of development of MN GSG. 
CoreGIS, is implemented in missions, a local version of classified network is used alongside. When somebody is searching for specific information, due to this redundancy, the output can be chaotic. KFOR has its own geospatial web service IGEOSIT which is separated from CoreGIS. This local service is reconciled with CoreGIS every now and then (Rada 2017). One single centralized web service accessible also in missions abroad is a way how to avoid possible misinterpretation of information caused by two separate sources. Access of all NATO nations at a national level to the web service CoreGIS should ensure wider interoperability. National military geographic services would be more flexible and efficient in contribution to joint effort of NATO. In general, they would follow the principle „work on the same map ". Nevertheless, the solution does not have a priority among other NATO projects as its national implementation is debatable.

\section{Conclusion}

Development of geospatial support in NATO reflects current security situation in the world. The aim is to create "SMART DEFENCE", a flexible technical support of deployed troops, and effectively, swiftly and safely secure flow of continuous information. The achievement of set objectives evaluated in the article is dependent particularly on economic conditions of individual nations and on willingness to make concessions to accomplish a common goal. Proposed changes that are already being partially implemented at the moment, might significantly contribute to reach full operability of the „smart geospatial defence ". Upcoming projects will also enable civilian organizations and experts to participate on building of smart defence goals on the national level.

\section{References}

Bělka L (2015) TREx - a New Multinational Project of the Elevation Data Production. Vojenský geografický obzor 58(2): 9-11.

Burns R., Jones J (2016) Restoring the power and purpose of the NATO alliance. Brent Snowcroft Center on international security.

Bortl D (2014) Looking Back on the Action of Geospatial Military Specialists in the Province Reconstruction Team (PRT) Logar, Afghanistan. Vojenský geografický obzor 1/2014: 3-8.
Centrum doktrín Velitelství výcviku - Vojenské akademie (2016) Pub-28-68-03: Geografické zabezpečení operací. Vojenská doktrína. Vyškov, Česká republika - Ministerstvo obrany.

George J, Sandler T (2018) Demand for military spending in NATO, 1968-2015: A spatial panel approach. European Journal of Political Economy 53: 222-236.

Kopecký R, Stránský J (2013) Application „Mapy AČR “. Vojenský geografický obzor 56(2): 13-15.

Kovařík V (2016) Geografické zabezpečení Tvorba rychlých mapových výstupů. University of defence. UNOB, Brno.

Marša J (2010) Geospatial support of the NATO strategic command. Vojenské rozhledy 19(3): 116-126.

Marša, J (2014) Long term objectives of geographical support of the Ministry of defence resort and their realisation, ArcRevue 4/2014: 4-7.

Multinational Geospatial Support Group (2017) NU MNGSGCONOPS. Euskirchen, Geoservice Bundeswehr.

Multinational Geospatial Support Group (2018) NU MNGSGAerodrome-Survey-Obstacle data collection objects, version 0.93. Euskirchen, Geoservice Bundeswehr

Nation Master. NATO Countries. Available at: https://www.nationmaster.com/country-info/groups/NATO-countries, [cit. 30.1.2019].

Rada J (2018) Analysis of quality of geospatial support in foreign missions. Vojenské rozhledy 27(2): 71-82.

Rada J (2017) Current trend in geospatial support in mission KFOR. Vojenský geografický obzor 2/2017: 25-33.

NATO Military Agency for Standardization (1979) STANAG 3600: Topographical Land Maps and Aeronautical Charts 1:250,000 for Joint Operations, Edition 3. NATO, Brussels.

NATO Standardization Agency (2013) STANAG 2586: NATO Geospatial Metadata Profile, Edition 1. NSA, Brussels.

NATO Standardization Office (2016) STANAG 2211: Geodetic Datums, Projections, Grids and Grid References, Edition 7. NSO, Brussels.

NATO Standardization Office (2014) STANAG 2592: NATO Geospatial Information Framework (NGIF), Edition 1. NSO, Brussels.

NATO Standardization Office (2016) AJP 3.17: Allied Joint Doctrine for Geospatial Support. NSO, Brussels.

NATO Standardization Office (2016) STANAG 2599: Allied Joint Doctrine for Geospatial Support, Edition 1. NSO, Brussels.

NATO Standardization Office (2017) MC 296/3: NATO Geospatial Policy. NSO, Brussels.

Statista, Number of military personnel in NATO countries in 2018. Available at: https://www.statista.com/statistics/584286/number-of-military-personnel-in-nato-countries/, [cit. 30.1.2019].

Wildmann R, Bělka L, Kotlář V (2009) Production of foreign territory maps: MGCP Derived Graphics. ArcRevue 2009/3. 